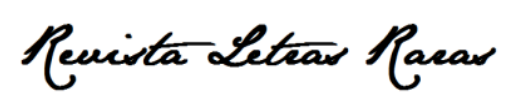

ISSN: 2317-2347

\title{
Guidelines for Reviewers
}

Dear LRJ reviewer, these step-by-step instructions were prepared to guide you through the OJS platform when designated to review a manuscript. For that purpose, follow the steps:

1 st STEP: Pay attention to the deadlines established in the designation e-mail you received. The first deadline is to confirm your availability to review a manuscript. The second deadline is to send your note to the editor. For both deadlines, follow the subsequent procedures.

$2^{\text {nd }}$ STEP: Access the LRJ website: http://revistas.ufcg.edu.br/ch/index.php/RLR and enter your login and password on the right side of the page.

(There is a password reset link on the designation e-mail you received, in case you have forgotten your password. If you are not able to reset it, please, contact us.)

\section{ATTENTION: If you access the submission page through the direct link to it (which was sent via e-mail), it is still necessary to be logged in to the system. On the contrary, the page will not open.}

$3^{\text {rd }}$ STEP: Once logged in, click on the link " 1 active" (if you are designated to review more than one manuscript, the quantity of links will evidently vary. For example: 2 active, 3 active...)

Revista Letras Raras

\begin{tabular}{|c|c|c|c|}
\hline $\begin{array}{l}\text { HOME ABOUT } \\
\text { INSTITUTIONAL DATA }\end{array}$ & $\begin{array}{l}\text { H CURRENT ARCHIVES } \\
\text { GUIDELINES FOR EVALUATORS }\end{array}$ & $\begin{array}{l}\text { ANNOUNCEMENTS } \\
\text { EVALUATION FORM }\end{array}$ & LABORATORY OF STUDIES LELLLC \\
\hline \multicolumn{4}{|l|}{ Home > User Home } \\
\hline \multicolumn{4}{|l|}{ User Home } \\
\hline \multicolumn{4}{|l|}{ Revista Letras Raras } \\
\hline $\begin{array}{l}\text { Author } \\
\text { Reviewer }\end{array}$ & 6 Archive & & [New Submission] \\
\hline
\end{tabular}




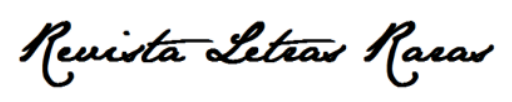

ISSN: 2317-2347

$4^{\text {th }}$ STEP: The following page displays the title of the manuscript to be evaluated, as shown in the example below (image). Then, click on the manuscript's title.

Revista Letras Raras

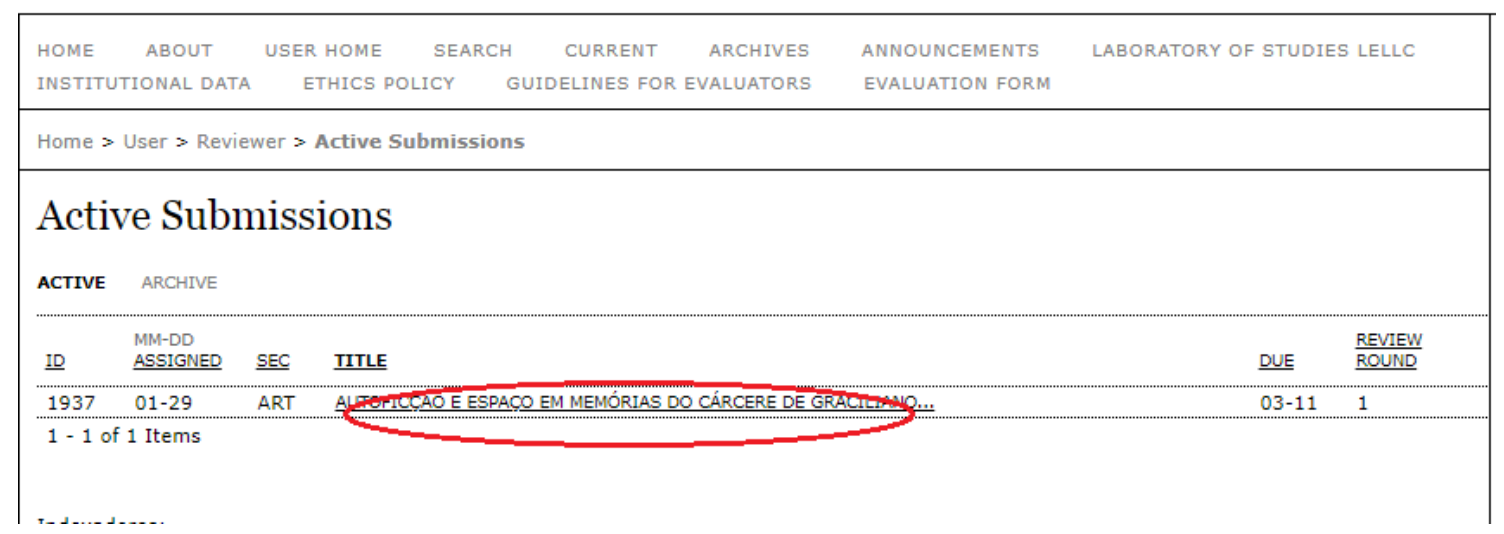

$5^{\text {th }}$ STEP: You will be directed to: \#Review; after that, scroll down to "Review steps", as shown in the example below.

To confirm that you will be the reviewer of the manuscript, click on "Will do the review"

To inform that you will not be able to review the manuscript, click on "Unable to do the review".

Attention: it is important to confirm availability (or the contrary), since if you are not able to review the manuscript, we need to designate another reviewer to appreciate the manuscript in a timely manner. 


\section{Penista Leteas Pacas}

ISSN: 2317-2347

Review Schedule

$\begin{array}{ll}\text { Editor's Request } & 2021-01-29 \\ \text { Your Response } & - \\ \text { Review Submitted } & - \\ \text { Review Due } & 2021-03-11\end{array}$

\section{Review Steps}

1. Notify the subpinsions editores to whetberyou will undertake the review.

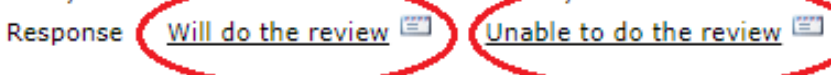

2. If you are going to do the review, consult Reviewer Guidelines below.

3. Click on file names to download and review (on screen or by printing) the files associated with this submission. Submission will be made available, if and when reviewer agrees to undertake review

4. Click on icon to fill in the review form.

Review Form 管

5. In addition, you can upload files for the editor and/or author to consult.

Uploaded files None

Escollher arquivo Nenhum arquivo selecionado Upload

$6^{\text {th }}$ STEP: If you confirm to be able to review the manuscript, the following page will be displayed (image below). Just click on "Send" (the body of the e-mail will be generated automatically).

\section{Send Email}

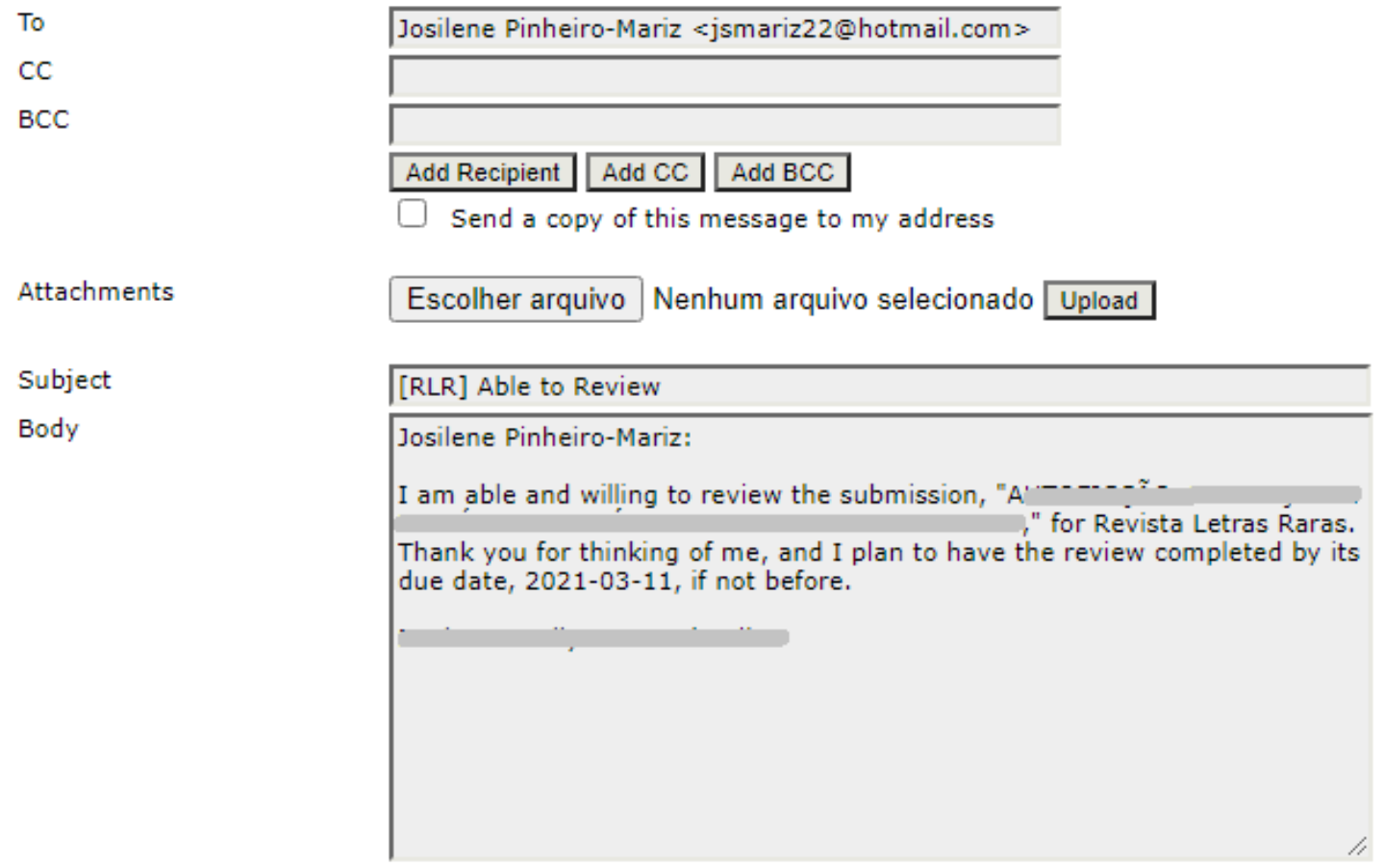




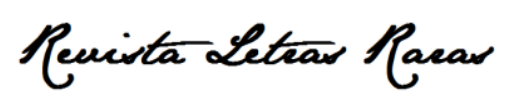

ISSN: 2317-2347

7th STEP: After that, you will be directed to the same page of \#Review, but, this time, you will have access to the manuscript (without authorship identification). To open the file, scroll down to "Review steps".

\section{ATTENTION (follow the steps observing the image below):}

7.1 In " 3 ", you will have access to the "submission manuscript" (the file of the text you are to review). To download the file to your computer, just click on the highlighted area.

7.2 After reading the manuscript, and including your observations and suggestions by adding comment balloons to the submitted text, it is time to fill the 'Review Form', in step " 4 ".

7.3 In " 4 ", click on the icon/balloon to fill the review form. After that, in step " 5 ", it is possible to upload the manuscript, with your comments and observations.

Attention: when reading the manuscript and inserting comments with improvement suggestions, it is highly recommended that the comments balloons do not have your identification, to guarantee a confidential review. In case you do not know how to remove your identification, when using the program Word, we advise you to watch this brief video: https://www.youtube.com/watch?v=HrRfUR3IqEs.

7.4 After finalizing the two steps of review and appreciation, you have to access the platform again. Then, go to active evaluation, and in "Review Steps" (note item "5" in the image below) click on "Escolher arquivo", and do not forget to click on "upload". If you do not click on "upload", the file will not be sent to the RLR platform. 


\section{Reuista Letras Racas}

ISSN: 2317-2347

By clicking in "Escolher arquivo", you will select the file of the manuscript you reviewed (the one with your comments). Then, click on open $->$ transfer.

7.5 To finish the upload of the manuscript, in item " 6 ", click on "choose one" and select your recommendation: accept; mandatory corrections; submit again to evaluation; submit to another journal or reject. After that, click on "Submit Review to Editor".

\section{Review Steps}

1. Notify the submission's editor as to whether you will undertake the review. Response Accepted

2. If you are going to do the review, consult Reviewer Guidelines below.

3. Click on file names to download and reviey (on screen or by nrintina) the files_associated with this submission. Submission Manuscript Supplementary File(s)

4. Click on icon to fill in the review form.

Review Form $\square$

5. In addition, you can upload files for the editor and/or author to consult.

Uploaded files \begin{tabular}{|l|l|l|l|l|l|l|}
\hline Escolher arquivo Nenhum arquivo selecionado & Upload \\
\hline
\end{tabular}

\section{4}

6. Select a recommendation and submit the review to complete the process. You must enter a review or upload a file before selecting a recommendation.

Recommendation

n $\therefore \cdot 1$.

If you have any doubt, do not hesitate to contact us. 